DOI: 10.1002/adsc.200505227

\title{
Supported Ionic Liquids. New Recyclable Materials for the L-Proline-Catalyzed Aldol Reaction
}

\author{
Michelangelo Gruttadauria, ${ }^{\mathrm{a}, *}$ Serena Riela, ${ }^{\mathrm{a}}$ Carmela Aprile, ${ }^{\mathrm{b}}$ Paolo Lo Meo, ${ }^{\mathrm{a}}$ \\ Francesca D'Anna, ${ }^{\mathrm{a}}$ Renato Noto ${ }^{\mathrm{a}, *}$ \\ a Dipartimento di Chimica Organica "E. Paternò”, Università di Palermo, Viale delle Scienze, Pad. 17, 90128 Palermo, \\ Italy \\ Fax: (+39)-(0)91-596-825, e-mail: mgrutt@unipa.it \\ b Departamento de Quimica, Universidad Politecnica de Valencia, Camino de Vera s/n, 46022 Valencia, Spain \\ Fax: (+34)-96-387-7809, e-mail: caprile@qim.upv.es
}

Received: June 1, 2005; Accepted: October 18, 2005

\begin{abstract}
New materials for L-proline recycling have been developed. These materials have been applied to the L-proline-catalyzed aldol reaction between acetone and several aldehydes. The L-proline has been supported on the surface of modified silica gels with a monolayer of covalently attached ionic liquid with or without additional adsorbed ionic liquid. Good yields and ee values, comparable with those obtained under homogeneous conditions, have been obtained especially with imidazolinium-modified and 4-methylpyridinium-modified silica gels. Moreover, these ma-
\end{abstract}

terials have been easily recovered by simple filtration and studies about their reuse have been carried out. These studies showed that these materials can be used at least up to seven times. Finally, in the case of imidazolinium-modified silica gel, investigations showed that this support can be regenerated giving again a recyclable material with high isolated yields and reproducible ee values up to 13 cycles.

Keywords: aldol reaction; $\beta$-hydroxy ketones; ionic liquids; organic catalysis; silica gel; supported catalyst

\section{Introduction}

The aldol reaction ${ }^{[1]}$ is one of the most important carbon-carbon bond-forming reactions in synthetic organic chemistry. Enantiomerically pure $\beta$-hydroxy ketones are important building blocks ${ }^{[2]}$ for the synthesis of polyfunctional compounds and natural products. Indeed, the $\beta$-hydroxy ketone structural motif is often found in several biologically active compounds, such as macrolide antibiotics and anti-cancer drugs. Moreover, the chirality at the hydroxy center can also be used to generate or control the stereochemistry at other sites. Then synand anti-1,3-diols $^{[2 \mathrm{~d}, 3]}$ as well as $s y n$-1,3-amino alcohols, ${ }^{[4]}$ which are important functional groups found in many biologically active compounds, can be obtained. Finally, the aldol reaction can be carried out as an atom-economy reaction. ${ }^{[5]}$

Several methods have been reported for the stereoselective synthesis of $\beta$-hydroxy ketones. Among them, the most known methods are, probably, those employing the use of a stoichiometric amount of chiral auxiliaries, ${ }^{[6]}$ or the use of metal-based catalysts. ${ }^{[7]}$ Other interesting methods have been developed such as addition of trichlorosilyl enolates to aldehydes in the presence of chi- ral phosphoramides, ${ }^{[8]}$ enzymatic transformations such as baker's yeast reduction of 1,3-diketones, ${ }^{[9]}$ the use of aldolase antibodies ${ }^{[10]}$ and the kinetic resolutions of racemic $\beta$-hydroxy ketones. ${ }^{[11]}$

Catalysis of asymmetric reactions by simple metalfree organic molecules (organocatalysis) is currently receiving immense interest. ${ }^{[12]}$ Among such reactions, the direct asymmetric intermolecular organocatalytic aldol reaction mediated by L-proline, which furnished $\beta$-hydroxy ketones, has been reported. ${ }^{[13]}$ Since then many papers have been published on this topic. ${ }^{[14]}$ These reactions are very useful since the products are obtained from good to high enantiomeric excess without prior modification of the ketone substrates such as deprotonation or silylation. Proline and its derivatives operate by bifunctional catalysis: the amine functionality activates the aldol donor molecules by converting them into enamines, whereas the carboxylic acid moiety provides a hydrogen bond to the acceptor. The enamine attacks the carbonyl group of the aldehyde acceptor with high enantiofacial selectivity. ${ }^{[15]}$

In order to reach better selectivities or reaction rates, several authors have carried out the proline-catalyzed aldol reaction under high pressure ${ }^{[16]}$ or by addition of 
$1-10$ equivalents of water ${ }^{[17]}$ or through a modification of the proline structure. ${ }^{[18]}$

The L-proline catalyzed aldol reaction is usually carried out under homogeneous conditions. The separation of the products from the reaction mixture and the recovery of the catalysts are the major disadvantages in the homogeneous catalytic process. For such economical and environmental reasons the recovery and reuse of such catalysts has became an important area of research. ${ }^{[19]}$ More recently, room-temperature ionic liquids (RTIL) have became very useful solvents for synthesis and catalysis. ${ }^{[20]}$

Several methods have been studied for the L-proline recovery. In the first full work on the L-proline-catalyzed aldol reaction, ${ }^{[13 \mathrm{~b}]}$ two routes were reported for this purpose. The first method was based on the fact that proline is not soluble in chloroform. The reaction carried out in this solvent allowed a facile recovery of the proline catalyst by filtration. The second approach was based on the immobilization of the proline on a silica gel column. Both methods gave a reduced enantiomeric excess. Good yields and ee values, compared to those obtained using non-supported proline, were obtained by poly(ethylene glycol)-supported proline. ${ }^{[21]} \mathrm{Up}$ to four cycles were reported with virtually unchanged ee values, but in slowly diminishing yields. Furthermore, three studies about the use of L-proline in ionic liquid as reusable catalyst for aldol reaction were reported. ${ }^{[22]}$ In both cases bmimPF $_{6}$ was the ionic liquid of choice. Good yields and good to high ee values were obtained. Recycling studies showed slightly diminished yields and ee values. In one case excellent enantioselectivities, even after four recycles, were found in the cross-aldol reactions. ${ }^{[2 \mathrm{c}]}$ However, in this case DMF was used as co-solvent. Interesting results were obtained for the reaction carried out in poly(ethylene glycol). ${ }^{[23]}$

Recently we reported the use of a supported ionic liquid phase for L-proline recycling. ${ }^{[24]}$ We called this example supported ionic liquid asymmetric catalysis. Mehnert ${ }^{[25]}$ has described the supported ionic liquid catalysis concept which combines the advantages of ionic liquids with those of heterogeneous support materials. The preference for heterogeneous catalyst systems is motivated by the advantage of easy separation and the ability to use fixed-bed reactors. Moreover, since ionic liquids are expensive it is desirable to minimize the amount of ionic liquid used in usual biphasic reaction systems. This can be realized with the supported ionic liquid catalysis which involves the treatment of a monolayer of covalently attached ionic liquid on the surface of silica gel with or without additional ionic liquid. These layers serve as the reaction phase in which the homogeneous catalyst is dissolved.

In our first communication we have applied the concept of supported ionic liquid asymmetric catalysis to L-proline-catalyzed asymmetric aldol reaction. ${ }^{[2]} \mathrm{We}$ found that $\mathrm{L}$-proline supported in this manner is an inter- esting material for the above reaction. Here we report further results about these investigations.

\section{Results and Discussion}

In order to investigate the effect of the nature of the ionic head of the modified silica gel we prepared imidazolium-modified silica gels 4-6 in which we changed the anion, silica gel 9 having a different charge distribution and silica gel 12 having different steric and charge distribution properties. Finally, silica gel 13, which does not possess any ionic head, was also prepared.

First we prepared compounds 2 and 3. The reaction between (3-chloropropyl)trimethoxysilane and 1,2-dimethylimidazole gave 1-(3-trimethoxysilylpropyl)-2,3dimethylimidazolium chloride (1). The chloride $\mathbf{1}$ was treated with either sodium tetrafluoroborate or sodium hexafluorophosphate in acetone to give the corresponding derivatives $\mathbf{2}$ and $\mathbf{3}$. Then, pretreated silica gel (Merck 0.063-0.2 mm) was refluxed with a chloroform solution of compounds $\mathbf{1}-\mathbf{3}$ to give, after a condensation reaction, the modified supported materials 4-6. Following the same procedure we prepared 1-(3-trimethoxysilylpropyl)-4-methylpyridinium chloride (7) and 1-(3-trimethoxysilylpropyl)-4-aza-1-azoniabicyclo[2.2.2]octane chloride (10). These salts were then transformed into the corresponding tetrafluoroborate salts 8 and 11. Finally, the modified silica gels $\mathbf{9}$ and $\mathbf{1 2}$ were prepared.

The anchorage of the trimethoxysilyl derivatives was proved by solid state ${ }^{13} \mathrm{C}$ NMR, IR and UV spectra. For example, the IR and UV spectra of $\mathbf{9}$ showed the bands of the parent ionic liquid $\left(v=1633 \mathrm{~cm}^{-1} ; \lambda=226\right.$ and $256 \mathrm{~nm}$ ). The solid state ${ }^{13} \mathrm{C}$ NMR spectrum of 9 (Figure 1) showed similar signals as 8 (see Experimental Section) except for the almost complete disappearance of the signal corresponding to the methoxy group. These results confirm the condensation reaction between the methoxy groups of $\mathbf{8}$ and the surface silanol groups of silica gel. Moreover, the main structure of $\mathbf{8}$ is maintained after the grafting process. The small peak at $50.6 \mathrm{ppm}$ was assigned to the residual signal of the methoxy group. This is due to the fact that several groups are maintained after the condensation reaction. In Figure 2 the solid state ${ }^{13} \mathrm{C}$ NMR spectrum of $\mathbf{4}$ is shown. In this case the $\mathrm{CH}_{3} \mathrm{O}$ and $\mathrm{CH}_{2} \mathrm{~N}$ signals have very similar chemical shifts (see ${ }^{13} \mathrm{C}$ NMR spectrum of 2 ), so the disappearance of the former signal cannot be proved but, again the main structure of $\mathbf{2}$, after the grafting process, is demonstrated.

Next we prepared the supported proline materials. We prepared two series of materials, the first one in which the L-proline was supported on the modified silica gels 4, 5, 6, 9 and 12 (4/pro, 5/pro, 6/pro, 9/pro and 12/pro) and the second one in which the L-proline was supported on the modified silica gels with additional ionic liquid (4/ bmimBF $_{4} /$ pro, $9 / 4 \mathrm{mbpBF}_{4} /$ pro). We also supported the 

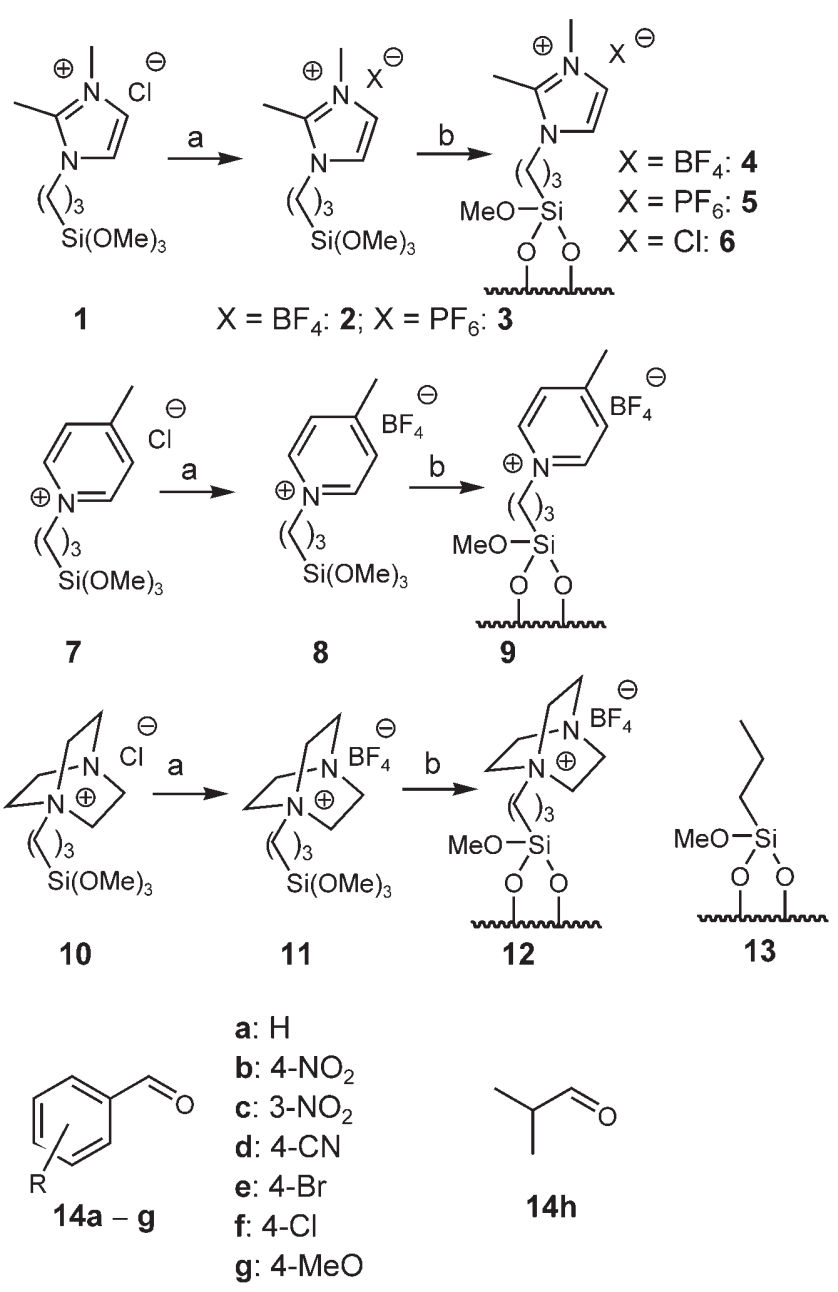

Scheme 1. Reagents and conditions: (a) $\mathrm{NaBF}_{4}$ or $\mathrm{NaPF}_{6}$, acetone, room temperature, 3 days; (b) $\mathrm{SiO}_{2}, \mathrm{CHCl}_{3}, 65^{\circ} \mathrm{C}$, $26 \mathrm{~h}$.

L-proline on unmodified silica gel containing adsorbed ionic liquid $\left(\mathrm{SiO}_{2} / \mathrm{bmimBF}_{4} /\right.$ pro, $\mathrm{SiO}_{2} / 4 \mathrm{mbpBF}_{4} /$ pro $)$. In order to investigate the effect of the ionic head, we also supported L-proline on propyl-modified silica gel $13(13 /$ pro) . These materials were prepared by adding the modified silica gel to a water/acetonitrile or ionic liquid/water/acetonitrile solution containing L-proline. After the solvent was removed under reduced pressure a powder was obtained.

In Table 1 are reported morphological properties (BET surface area, BJH average pore diameter and cumulative pore volume) of several materials. Modification of the starting silica gel (entry 11) with covalently attached ionic liquid (entries 1-4) gave materials with a lower surface area. In the imidazolinium-modified silica gels the surface area decreased starting from the more coordinating anion to the less coordinating anion. ${ }^{[26]}$ Silica gel $\mathbf{9}$, which has the same anion of silica gel $\mathbf{4}$, but a cation with a different charge distribution (i.e., a more

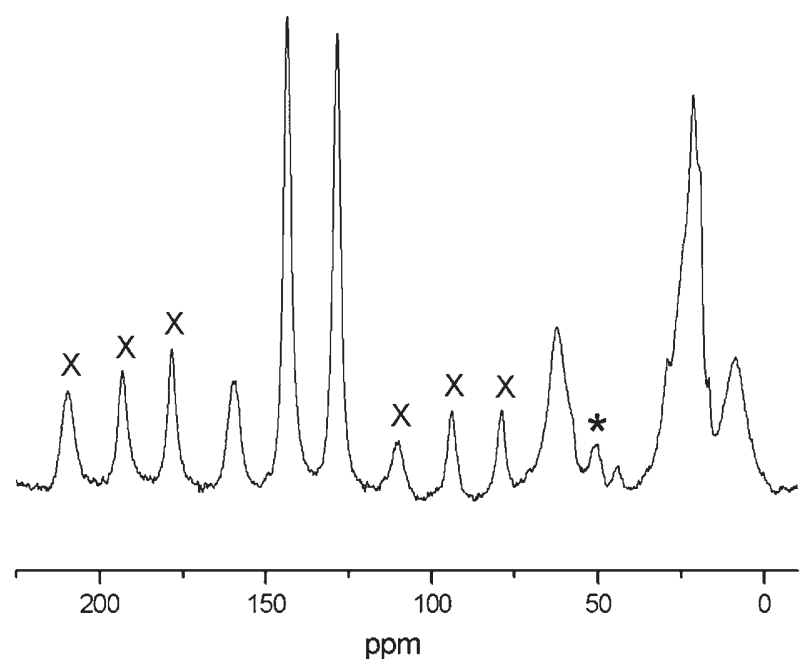

Figure 1. Solid state ${ }^{13} \mathrm{C}$ NMR spectrum of 9. Side bands (x). Residual $\mathrm{CH}_{3} \mathrm{O}$ signal (*).

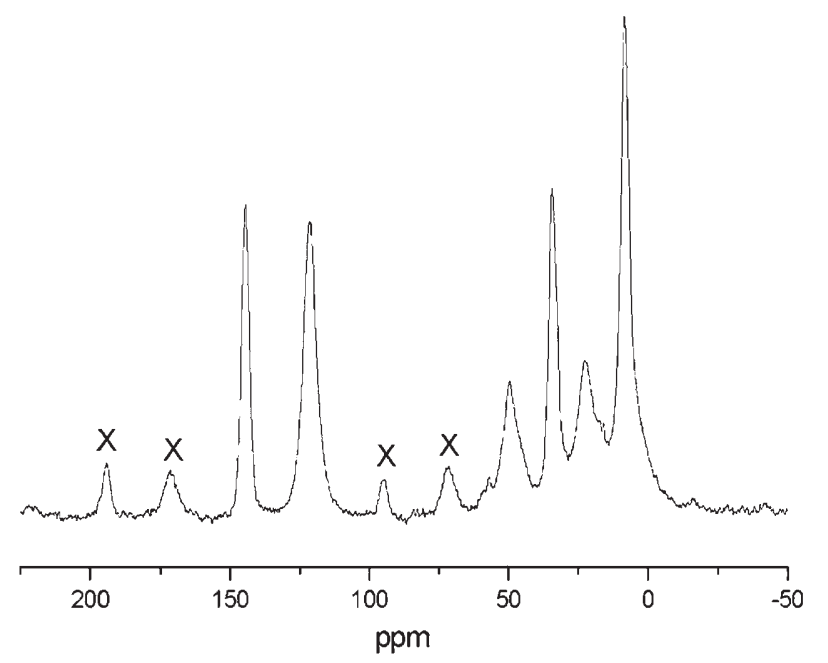

Figure 2. Solid state ${ }^{13} \mathrm{C}$ NMR spectrum of 4 . Side bands (x).

localized charge), showed, in agreement with the above trend, a higher surface area.

Lower surface areas and similar pore diameters, compared to silica gels 4-6 and 9, were observed when proline or ionic liquid/proline were adsorbed (entries 5 and $7-10$ ). Only in the case of silica gel $\mathbf{5}$, a small increase in the surface area value and a smaller pore diameter was observed. This difference can be ascribed to the hydrophobic nature of the $\mathrm{PF}_{6}{ }^{-}$-modified silica gel 5. Since proline was added from an aqueous solution, probably it was adsorbed in a different manner.

At first we investigated the aldol reaction between acetone and benzaldehyde. The reaction was carried out by simply mixing the supported L-proline $(30 \% \mathrm{~mol})$ with acetone and benzaldehyde at room temperature for $24 \mathrm{~h}$. The $4 /$ pro system gave interesting results (Table 2, entry 7 ). The aldol product was isolat- 
Table 1. Morphological properties of several materials

\begin{tabular}{|c|c|c|c|c|}
\hline Entry & Catalytic system & $\mathrm{SSA}^{[\mathrm{a}]}\left[\mathrm{m}^{2} / \mathrm{g}\right]$ & $\begin{array}{l}\text { Average pore } \\
\text { diameter }^{[b]}[\AA]\end{array}$ & $\begin{array}{l}\text { Cumulative pore } \\
\text { volume }\left[\mathrm{cm}^{3} / \mathrm{g}\right]\end{array}$ \\
\hline 1 & 4 & 279 & 60 & 0.47 \\
\hline 2 & 5 & 202 & 60 & 0.41 \\
\hline 3 & 6 & 340 & 43 & 0.44 \\
\hline 4 & 9 & 317 & 47 & 0.45 \\
\hline 5 & 4/pro & 175 & 63 & 0.35 \\
\hline 6 & 5/pro & 230 & 47 & 0.34 \\
\hline 7 & 6/pro & 279 & 43 & 0.38 \\
\hline 8 & 9/pro & 166 & 49 & 0.25 \\
\hline 9 & 4/bmimBF bro $_{4} /$ pro & 58 & 50 & 0.13 \\
\hline 10 & $\mathbf{9} / 4 \mathrm{mbpBF}_{4} /$ pro & 19 & 39 & 0.03 \\
\hline 11 & $\mathrm{SiO}_{2}$ Merck & 453 & 59 & 0.62 \\
\hline
\end{tabular}

[a] BET specific surface area.

${ }^{[b]} \mathrm{BJH}$.

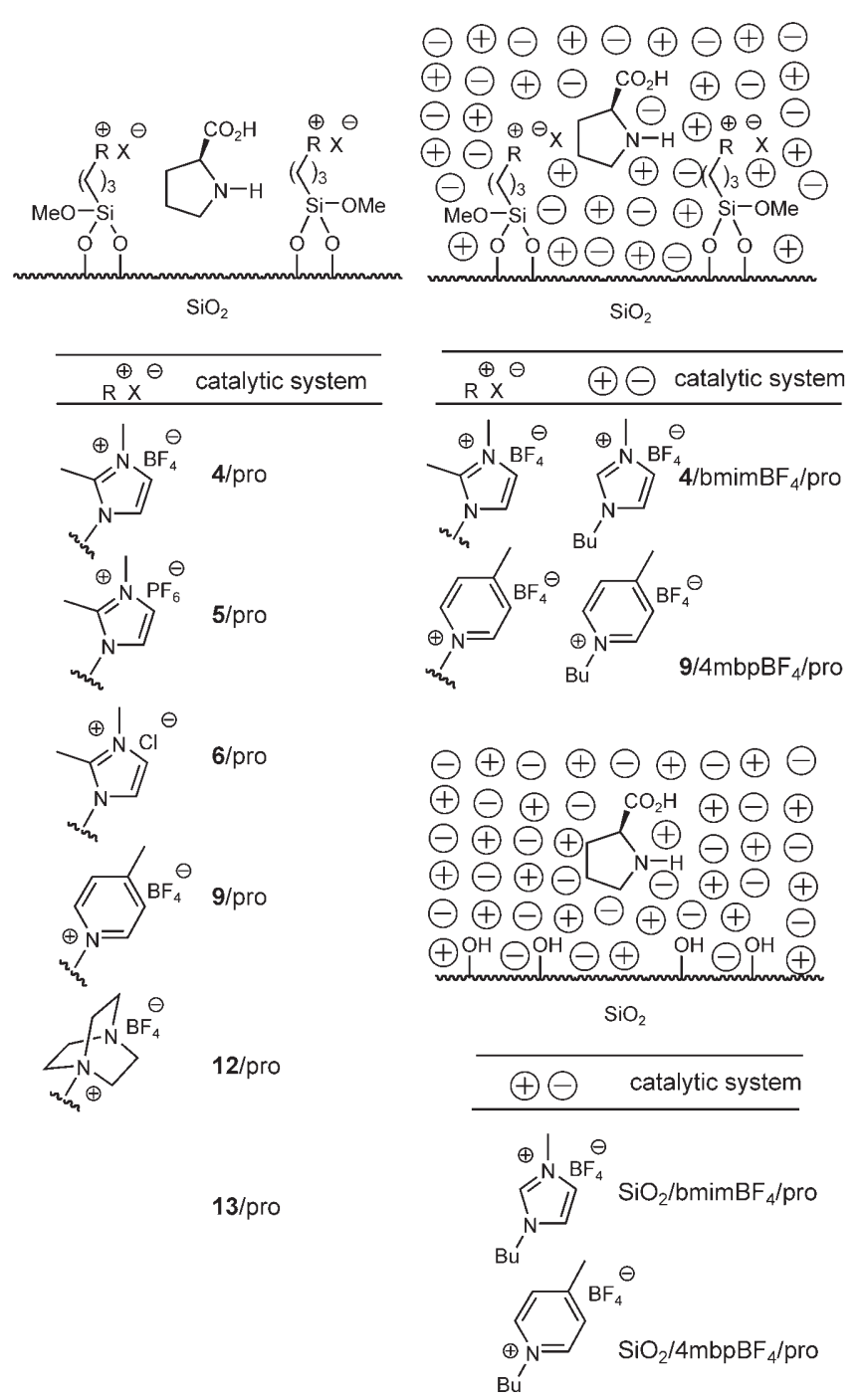

Figure 3. Catalytic systems used in this work.

ed, not in high yield but, with ee similar to that obtained under homogeneous conditions (Table 2, entry 1). The

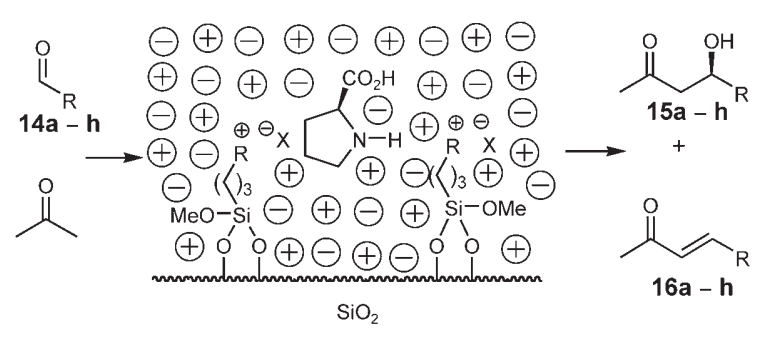

Figure 4. Supported ionic liquid asymmetric catalysis.

reactions carried out in pure ionic liquid gave similar results when $\mathrm{hmimBF}_{4}$ was used and higher ee when bmimPF$_{6}$ was used (Table 2, entries 2 and 3). Similar ees were obtained with L-proline dissolved in PEG and with the PEG-proline/DMF system (Table 2, entries 5 and 6). Next we carried out the reaction with 5/pro and 6/pro in order to study the effect of the anion. Both systems gave a lower ee value $(42 \%$, Table 2 , entries 8 and 9). Then, the best result was obtained with the $\mathrm{BF}_{4}{ }^{-}$-modified silica gel. The 5/pro system gave, at about the same conversion, less $\beta$-hydroxy ketone and more elimination product, whereas the 6/pro system gave higher conversion but also higher elimination product. The reaction carried out under homogeneous condition in the presence of omimCl gave also a high amount of elimination product. ${ }^{[22 \mathrm{~b}]}$

Then, we changed the cation from 1-propyl-2,3-dimethylimidazolium to 1-propyl-4-methylpyridinium (9/ pro, Table 2, entry 10). In this case a slightly increased ee value was observed. Then, we totally changed the nature of the ionic head. With the 1-propyl-1-(3-trimethoxysilylpropyl)-4-aza-1-azoniabicyclo[2.2.2] octane cation (12/pro, Table 2, entry 11) the yield was low and no enantioselectivity was observed. Finally, we carried out the reaction with the propyl-substituted silica gel (13/pro, Table 2, entry 12). In this case the yield was low and, again, a very low enantioselectivity was ob- 


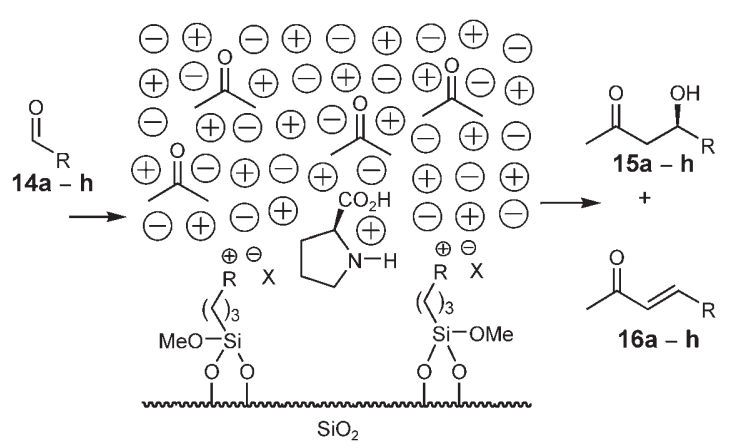

Figure 5. Reaction in the presence of $\mathbf{4} / \mathrm{bmimBF}_{4} /$ pro or $\mathbf{9} /$ $4 \mathrm{mbpBF}_{4} /$ pro systems.

served. These results clearly show the great importance of the nature of the supported ionic liquid phase. Probably, $\pi-\pi$ interactions between the heterocyclic ring and the carbonyl group play a role.

We then turned our attention to examining the behaviour of the $4 / \mathrm{bmimBF}_{4} /$ pro and $9 / 4 \mathrm{mbpBF}_{4} /$ pro systems in order to investigate the effect of the adsorbed ionic liquid. The $4 / \mathrm{bmimBF}_{4} /$ pro system gave the same ee (64\%, Table 2 , entry 13 ) with respect to the $4 /$ pro system but, with a slightly better yield. The 9/pro and 9/ $4 \mathrm{mbpBF}_{4} /$ pro systems gave also the same ee value but, in this case a better yield was obtained using the $9 /$ pro system (Table 2, entries 10 and 14). These results showed that the additional adsorbed ionic liquid did not affect the ee of the product.
The addition of the adsorbed ionic liquid gave materials with low surface area (see Table 1), then we can argue that the surface area should not affect the ee values. However, since the bmimBF 4 and $4 \mathrm{mbpBF}_{4}$ ionic liquids are miscible with acetone, it is possible that in the case of $4 / \mathrm{bmimBF}_{4} /$ pro and $9 / 4 \mathrm{mbpBF}_{4} /$ pro systems the reaction takes place as depicted in Figure 5. If this happens, the surface area should not be what we measured but, probably that of the corresponding 4/pro or 9/pro material. At the end of the reaction, when acetone was removed, the $4 / \mathrm{bmimBF}_{4} /$ pro and $\mathbf{9} / 4 \mathrm{mbpBF}_{4} /$ pro systems were formed again.

We also investigated the behaviour of unmodified silica gel with adsorbed ionic liquid phase $\left(\mathrm{SiO}_{2} / \mathrm{bmimBF}_{4} /\right.$ pro, entry $15 ; \mathrm{SiO}_{2} / 4 \mathrm{mbpBF}_{4} /$ pro, entry 16$)$. In both cases the ee was very low, particularly with the $\mathrm{SiO}_{2} /$ $4 \mathrm{mbpBF}_{4} /$ pro system.

After these preliminary results we started investigations about the regenerability of the system. We chose the $9 /$ pro and the $4 / \mathrm{bmimBF}_{4} /$ pro systems.

Whereas bmimBF and $_{4}$ bmimPF $_{6}$ have been used for the homogeneous proline-catalyzed aldol reaction, ${ }^{[22]}$ the use of 1-butyl-4-methylpyridinium tetrafluoroborate $\left(4 \mathrm{mbpBF}_{4}\right)$ has not been reported.

Then, we carried out several reactions in homogeneous conditions (Table 3 ) in order to compare these results with those obtained under heterogeneous conditions.

Isolated yields from 50 to $77 \%$ and good ee values have been observed. With $p$-nitrobenzaldehyde a lower

Table 2. Aldol reaction between acetone and benzaldehyde ${ }^{[a]}$ (14a) with different L-proline catalyst forms.

\begin{tabular}{|c|c|c|c|c|c|}
\hline Entry & Catalytic system & $\mathbf{1 4 a}[\%]^{[\mathrm{b}]}$ & 15a $[\%]^{[\mathrm{b}]}$ & $16 \mathbf{a}[\%]^{[\mathrm{b}]}$ & ee $\mathbf{1 5 a}[\%]^{[\mathrm{c}]}$ \\
\hline $1^{[\mathrm{d}]}$ & Proline/DMSO & - & 62 & - & 60 \\
\hline $2^{[\mathrm{e}]}$ & Proline/hmimBF 4 & - & 50 & - & 58 \\
\hline $3^{[\mathrm{e}]}$ & Proline/bmimPF 6 & - & 58 & - & 71 \\
\hline $4^{[\mathrm{f}]}$ & Proline/bmimPF $_{6}$ & - & 55 & - & 76 \\
\hline $5^{[\mathrm{g}]}$ & Proline/PEG & - & 58 & - & 58 \\
\hline $6^{[\mathrm{h}]}$ & PEG-proline/DMF & - & 45 & - & 59 \\
\hline 7 & 4/pro & 18 & 40 & 9 & 64 \\
\hline 8 & 5/pro & 23 & 33 & 18 & 42 \\
\hline 9 & 6/pro & 6 & 49 & 41 & 42 \\
\hline 10 & 9/pro & 9 & 55 & 16 & 70 \\
\hline 11 & 12/pro & 25 & 12 & 5 & 0 \\
\hline 12 & 13/pro & 23 & 32 & 13 & 4 \\
\hline 13 & 4/bmimBF $/$ pro & 20 & 51 & 11 & 64 \\
\hline 14 & $\mathbf{9} / 4 \mathrm{mbpBF}_{4} /$ pro & 5 & 40 & 10 & 70 \\
\hline 15 & $\mathrm{SiO}_{2} / \mathrm{bmimBF}_{4} /$ pro & 44 & 38 & 6 & 12 \\
\hline 16 & $\mathrm{SiO}_{2} / 4 \mathrm{mbpBF}_{4} /$ pro & - & 43 & 8 & -4 \\
\hline
\end{tabular}

\footnotetext{
[a] Reaction time for entries 7-16: $24 \mathrm{~h}$.

[b] Isolated yield.

[c] Determined by chiral HPLC.

[d] Ref. ${ }^{[13]}$

[e] $\operatorname{Ref}^{[22 b]}$

[f] $\operatorname{Ref}^{[22 a]}$

${ }^{[g]} \operatorname{Ref}^{[23]}$

[h] $\operatorname{Ref}^{[21]}$
} 
Table 3. Aldol reactions in $4 \mathrm{mbpBF}_{4} /$ pro system. $^{[\mathrm{a}]}$

\begin{tabular}{llllll}
\hline Entry & $\mathbf{1 4}$ & $\mathbf{1 4}[\%]^{[\mathrm{b}]}$ & $\mathbf{1 5}\left[\% 9^{[\mathrm{b}]}\right.$ & $\mathbf{1 6}[\%]^{[\mathrm{b}]}$ & ee $\mathbf{1 5}[\%]^{[\mathrm{cc}]}$ \\
\hline 1 & $\mathbf{a}$ & 7 & 50 & 8 & 70 \\
2 & $\mathbf{b}$ & ${ }^{[\mathrm{d}]}$ & 75 & ${ }^{[\mathrm{d}]}$ & 48 \\
3 & $\mathbf{c}$ & ${ }^{[\mathrm{d}]}$ & 77 & ${ }^{[\mathrm{d}]}$ & 80 \\
4 & $\mathbf{d}$ & ${ }^{[\mathrm{d}]}$ & 70 & $-^{[\mathrm{d}]}$ & 72 \\
5 & $\mathbf{f}$ & ${ }^{[\mathrm{d}]}$ & 51 & 5 & 76 \\
6 & $\mathbf{g}$ & 95 & ${ }^{[\mathrm{d}]}$ & - & $\mathrm{nd}$ \\
\hline
\end{tabular}

[a] Reaction time $24 \mathrm{~h}$.

[b] Isolated yield.

[c] Determined by chiral HPLC.

[d] Detected on TLC but isolated in less than 3\% yield.

Table 4. Recycling studies with $9 /$ pro catalytic system. ${ }^{\text {[a] }}$

\begin{tabular}{lllllll}
\hline Entry & Cycle & $\mathbf{1 4}$ & $\mathbf{1 4}[\%]^{[\mathrm{b}]}$ & $\mathbf{1 5}[\%]^{[\mathrm{b}]}$ & $\mathbf{1 6}[\%]^{[\mathrm{b}]}$ & ee $\mathbf{1 5}[\%]^{[\mathrm{cc}]}$ \\
\hline 1 & 1 & $\mathbf{b}$ & $-^{[\mathrm{d}]}$ & 83 & 6 & 48 \\
2 & 2 & $\mathbf{b}$ & $-^{[\mathrm{d}]}$ & 83 & 6 & 50 \\
3 & 3 & $\mathbf{b}$ & 8 & 84 & 4 & 54 \\
4 & 4 & $\mathbf{b}$ & 5 & 75 & ${ }^{[\mathrm{d}]}$ & 48 \\
5 & 5 & $\mathbf{b}$ & 30 & 62 & 4 & 40 \\
6 & 6 & $\mathbf{c}$ & 70 & 28 & ${ }^{[\mathrm{d}]}$ & 74 \\
$7^{[\mathrm{e}]}$ & 7 & $\mathbf{c}$ & $-^{[\mathrm{d}]}$ & 93 & 4 & 4 \\
\hline
\end{tabular}

[a] Reaction time $24 \mathrm{~h}$.

[b] Isolated yield.

${ }^{[c]}$ Determined by chiral HPLC.

[d] Detected on TLC but isolated in less than 3\% yield.

${ }^{[\mathrm{e}]}$ Regenerated 9/pro.

ee was found whereas with $p$-methoxybenzaldehyde the reaction did not take place.

Compared to the homogeneous conditions, the 9/pro system gave the same ee value in the reaction with 14a with similar yield (see Table 2 entry 10 and Table 3 entry 1). In Table 4 are reported the recycling studies carried out with the $9 /$ pro system. At the end of each cycle the acetone was evaporated and the modified silica gel filtered with diethyl ether. It was dried for a few minutes under reduced pressure then reused. With aldehyde 14b a better yield was obtained with respect to the homogeneous conditions. Also in this case the ee was comparable. The $9 /$ pro material was used four times with similar ee values and yield. However, in the fifth run the conversion was lower. Moreover, a decrease in the ee value was observed. The material was used in a subsequent run with 14c. The conversion was low but, the ee was similar to that obtained under homogeneous conditions.

We also checked if the ee can be increased by working at a lower temperature $\left(-15^{\circ} \mathrm{C}\right)$. We carried out a reaction using fresh 9/pro system in the presence of $p$-nitrobenzaldehyde. The isolated yield was lower $(55 \%)$ but, interestingly, the ee was higher (68\%).

Since proline is adsorbed, we investigated the regeneration of the 9/pro material washing it with water to remove the adsorbed proline, drying and then recharging
Table 5. Recycling studies with $9 /$ pro $^{[a]}$ catalytic system. $^{[b]}$

\begin{tabular}{lllllll}
\hline Entry & Cycle & $\mathbf{1 4}$ & $\mathbf{1 4}[\%]^{[\mathrm{c}]}$ & $\mathbf{1 5}[\%]^{[\mathrm{c}]}$ & $\mathbf{1 6}[\%]^{[\mathrm{c}]}$ & ee $\mathbf{1 5}[\%]^{[\mathrm{d}]}$ \\
\hline 1 & 1 & $\mathbf{b}$ & ${ }^{[\mathrm{e}]}$ & 84 & 5 & 60 \\
2 & 2 & $\mathbf{c}$ & ${ }^{[\mathrm{e}]}$ & 82 & 18 & 76 \\
3 & 3 & $\mathbf{d}$ & 13 & 83 & 4 & 52 \\
4 & 4 & $\mathbf{f}$ & 30 & 20 & 5 & 74 \\
5 & 5 & $\mathbf{b}$ & 16 & 74 & 8 & 42 \\
$6^{[\mathrm{f}]}$ & 6 & $\mathbf{b}$ & ${ }^{[\mathrm{e}]}$ & 75 & 4 & 22 \\
\hline
\end{tabular}

[a] Prepared from L-proline dissolved in methanol.

[b] Reaction time $24 \mathrm{~h}$.

[c] Isolated yield.

[d] Determined by chiral HPLC.

[e] Detected on TLC but isolated in less than 3\% yield.

[f] Regenerated 9/pro.

with fresh proline. The reaction with $\mathbf{1 4 c}$ gave a very good yield but, without selectivity.

This result showed that water used for washing had a detrimental effect on the ee. It has already reported that the addition of water severely compromises the enantioselectivity. ${ }^{[13 b]}$

Because of the relatively large amount of water used for washing, some water has probably been retained even after drying (under reduced pressure for $24 \mathrm{~h}$ at $25^{\circ} \mathrm{C}$ ). Then, in order to avoid the presence of water and to investigate if by avoiding its use a better enantioselectivity can be reached, we prepared fresh 9/pro system by dissolving the L-proline in methanol. We also used this material for recycling studies (Table 5).

We obtained the aldol 15b in high yield and with an increased ee (60\%) compared to that obtained with 9/pro system prepared dissolving the proline in acetonitrile/ water (48\%, see Table 4, entry 1$)$. Recycling with different aldehydes showed similar ee values compared to the homogeneous conditions, except for compound 14d. However, in the fifth cycle a decrease in the ee was observed for $\mathbf{1 5 b}$.

After five cycles we checked the regenerability of the 9/pro material washing when it with methanol instead of water. After drying and recharging with fresh proline, the reaction with 14b gave the aldol in $75 \%$ yield and $22 \%$ ee.

Finally, we carried out again the reaction with $\mathbf{1 4 b}$ in the presence of fresh 9/pro prepared from methanol. In this case the reaction was stopped when the aldehyde was consumed, as monitored by TLC $(4.5 \mathrm{~h})$. Compound $\mathbf{1 5 b}$ was isolated in $80 \%$ yield along a $6 \%$ yield of $\mathbf{1 6 b}$. The ee of $\mathbf{1 5 b}$ was $62 \%$. Then, we can argue that the prolonged reaction time does not affect either the ee value or the amount of elimination product $\mathbf{1 6 b}$.

Next we investigated the $4 / \mathrm{bmimBF}_{4} /$ pro system. In our previous communication we have reported several aldol reactions with aldehydes $\mathbf{1 4 a}, \mathbf{b}, \mathbf{e}, \mathbf{g}, \mathbf{h}$ and short recycling studies. Good results were obtained both in terms of yields and ee values (e.g., aldehyde 14h gave the aldol product in $96 \%$ ee) ${ }^{[24]}$ Here we carried out sev- 
Table 6. Aldol reaction of compounds $\mathbf{1 4 b}, \mathbf{c}$ in the presence of $4 / \mathrm{bmimBF}_{4} / \mathrm{pro}^{[\mathrm{a}]}$ catalyst and recycling studies. ${ }^{[\mathrm{b}]}$

\begin{tabular}{|c|c|c|c|c|c|c|}
\hline Entry & Cycle & 14 & $\begin{array}{l}14 \\
{[\%]^{[c]}}\end{array}$ & $\begin{array}{l}15 \\
{[\%]^{[c]}}\end{array}$ & $\begin{array}{l}16 \\
{[\%]^{[c]}}\end{array}$ & $\begin{array}{l}\text { ee } \mathbf{1 5} \\
{[\%]^{[\mathrm{d}]}}\end{array}$ \\
\hline 1 & 1 & $\mathbf{b}$ & ${ }^{[\mathrm{e}]}$ & 85 & $-^{[\mathrm{e}]}$ & 66 \\
\hline 2 & 2 & $\mathbf{b}$ & ${ }^{[\mathrm{e}]}$ & 84 & ${ }^{[\mathrm{e}]}$ & 66 \\
\hline 3 & 3 & $\mathbf{b}$ & $-^{[\mathrm{e}]}$ & 93 & ${ }^{[}[\mathrm{e}]$ & 68 \\
\hline 4 & 4 & $\mathbf{b}$ & ${ }^{[\mathrm{e}]}$ & 90 & ${ }^{[\mathrm{e}]}$ & 70 \\
\hline 5 & 5 & b & ${ }^{[\mathrm{e}]}$ & 94 & ${ }^{[\mathrm{e}]}$ & 46 \\
\hline 6 & 6 & b & ${ }^{[\mathrm{e}]}$ & 91 & ${ }^{[\mathrm{e}]}$ & 42 \\
\hline 7 & 7 & c & 6 & 92 & ${ }^{[\mathrm{e}]}$ & 76 \\
\hline $8^{[\mathrm{f}]}$ & 8 & b & 13 & 82 & ${ }^{[\mathrm{e}]}$ & 42 \\
\hline $9^{[\mathrm{f}]}$ & 9 & c & 14 & 83 & ${ }^{[\mathrm{e}]}$ & 75 \\
\hline
\end{tabular}

[a] Prepared from L-proline dissolved in water/acetonitrile.

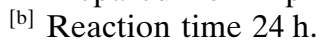

${ }^{[c]}$ Isolated yield.

[d] Determined by chiral HPLC.

[e] Detected on TLC but isolated in less than 3\% yield.

[f] Regenerated $\mathbf{4} / \mathrm{bmimBF}_{4} /$ pro.

en cycles using 14b,c. With aldehyde $14 b$ the reaction was carried out six times. Only aldol product was found with isolated yields ranging from 84 to $94 \%$ and good ee. The ee was lower than that in homogeneous conditions, but better than in ionic liquid. However, in the fifth and sixth cycles, even if the isolated yields were high, the ee decreased. In the seventh cycle aldehyde 14c was used. Again good yield and ee were obtained (Table 6, entry 7).

Even if in the last cycle both yield and ee were good, we investigated the regenerability of the system. The material was washed with methanol, dried, recharged with fresh proline and reused in the reaction with $\mathbf{1 4 b}$ and 14c. We got good yields but, with slightly lower conversion. In both cases the ee values was the same compared to that obtained before regeneration. The latter results are better than those obtained after regeneration of $9 /$ pro.

As final investigation we prepared the $4 / \mathrm{bmimBF}_{4} /$ pro system dissolving the proline in methanol. Then we carried out several recycling studies. It was used five times with $p$-nitrobenzaldehyde. High yields of compound $\mathbf{1 5 b}$ were obtained. Different results with regard to the ee value were observed compared to the $4 / \mathrm{bmimBF}_{4} /$ pro system prepared from proline dissolved in water/acetonitrile (Table 6). Indeed, while the first run gave a similar ee value, runs $2-4$ gave lower ee values (compare Table 6 entries $2-4$ and Table 7 entries 2-4). However, whereas with the former system a sudden drop in the ee value was observed (Table 6 entry 5), with the latter system the ee value was constant. In the sixth and seventh cycles lower conversions were observed with 14c and 14d, but good ee values were obtained. Particularly, in the case of compound $\mathbf{1 5} \mathbf{c}$ the ee value was higher than that observed with the former system (Table 6, entry 7). Since in the last two runs the conversions were not good,
Table 7. Aldol reaction of compounds $\mathbf{1 4 a}-\mathbf{d}$ in the presence of $4 / \mathrm{bmimBF}_{4} / \mathrm{pro}^{[\mathrm{a}]}$ catalyst and recycling studies. ${ }^{[\mathrm{b}]}$

\begin{tabular}{lclllll}
\hline Entry & Cycle & $\mathbf{1 4}$ & $\mathbf{1 4}[\%]^{[\mathrm{c}]}$ & $\mathbf{1 5}[\%]^{[\mathrm{c}]}$ & $16[\mathbf{\%}]^{[\mathbf{c}]}$ & ee $\mathbf{1 5}[\%]^{[\mathrm{d}]}$ \\
\hline 1 & 1 & $\mathbf{b}$ & $-^{[\mathrm{e}]}$ & 79 & 6 & 64 \\
2 & 2 & $\mathbf{b}$ & $-^{[\mathrm{e}]}$ & 91 & 6 & 58 \\
3 & 3 & $\mathbf{b}$ & $-^{[\mathrm{e}]}$ & 92 & 7 & 56 \\
4 & 4 & $\mathbf{b}$ & 2 & 92 & 5 & 56 \\
5 & 5 & $\mathbf{b}$ & 8 & 86 & 5 & 56 \\
6 & 6 & $\mathbf{c}$ & 51 & 49 & - & 84 \\
7 & 7 & $\mathbf{d}$ & 57 & 43 & - & 72 \\
$8^{[\mathrm{f}]}$ & 8 & $\mathbf{c}$ & - & 93 & 6 & 86 \\
$9^{[\mathrm{f}]}$ & 9 & $\mathbf{d}$ & $-{ }^{[\mathrm{e}]}$ & 89 & 8 & 74 \\
$10^{[\mathrm{f}]}$ & 10 & $\mathbf{b}$ & - & 79 & 15 & 50 \\
$11^{[\mathrm{f}]}$ & 11 & $\mathbf{a}$ & 35 & 37 & 27 & 72 \\
$12^{[\mathrm{f}]}$ & 12 & $\mathbf{c}$ & - & 95 & 5 & 78 \\
$13^{[\mathrm{f}]}$ & 13 & $\mathbf{c}$ & - & 94 & 5 & 76 \\
\hline
\end{tabular}

[a] Prepared from L-proline dissolved in methanol.

[b] Reaction time $24 \mathrm{~h}$.

[c] Isolated yield.

[d] Determined by chiral HPLC.

[e] Detected on TLC but isolated in less than 3\% yield.

[f] Regenerated 4/bmimBF $\mathrm{bm}_{4}$ pro.

the $4 / \mathrm{bmimBF}_{4} /$ pro system was regenerated as before. The regenerated system was used for further six cycles. Reaction with aldehydes 14c, 14d, 14b gave high isolated yields of the corresponding $\beta$-hydroxy ketones even in the last cycle. Moreover, good level of enantioselectivity was observed especially in the case of $\mathbf{1 5 a}$.

\section{Conclusion}

The useful level of isolated yields and ee values of $\beta$-hydroxy ketones, coupled with the very easy recovery, make these materials promising. We have shown that both the presence and nature of the ionic head on the surface of silica gel play an important role especially in order to reach a good level of enantiomeric excess. Moreover, the ionic liquid phase must be covalently attached in order to obtain good results. Indeed, with only an adsorbed ionic liquid phase no enantioselectivity was observed. Furthermore, we have minimized the amount of ionic liquid used in usual biphasic reaction systems. Both imidazolium- and picolinium-modified silica gel gave good results. Imidazolinium-modified silica gel gave high yields ( $>90 \%$ ) even after 7 cycles with interesting ee values, whereas picolinium-modified silica gel was used 6 times with good ee values but, with decreasing isolated yields.

Investigations about the possibility of regeneration of the catalytic systems showed that regenerated 9/pro system gave the aldol product with low ee values, especially when the material was washed with water. On the other hand $4 / \mathrm{bmimBF}_{4} /$ pro, regenerated after washing with methanol, gave reproducible ee values even after fur- 
ther six aldol reaction cycles. Indeed, the best results were obtained with the $4 / \mathrm{bmimBF}_{4}$ system with proline dissolved in methanol. The support (imidazolium tetrafluoroborate-modified silica gel 4) was used up to 13 cycles. It is easily recoverable and regenerable.

In conclusion, we have showed that ionic liquid modified silica gels could be interesting materials for supporting L-proline and further efforts will be devoted by us in their development and for a better understanding of their behaviour.

\section{Experimental Section}

${ }^{1} \mathrm{H}$ NMR and ${ }^{13} \mathrm{C}$ NMR spectra were recorded on a Bruker ACE series $250 \mathrm{MHz}$ spectrometer. FT-IR spectra were registered with a Nicolet 710 or with a Shimadzu FTIR 8300 infrared spectrophotometer. Diffuse reflectance UV/Vis spectroscopy was performed using a Cary 5 Varian using $\mathrm{BaSO}_{4}$ as standard.

Carbon and nitrogen contents were determined by combustion analysis in a Fisons EA 1108 elemental analyzer. Specific surface area and pore size distributions were measured by recording the nitrogen adsorption/desorption isotherms at liquid $\mathrm{N}_{2}$ temperature using a Micromeritics ASAP 2010 system. Pore size distribution was determined from the desorption branch of the isotherm by the BJH (Barrett-Joyner-Halenda) method using the Halsey equation. Solid-state ${ }^{13} \mathrm{C}$ MAS NMR spectra were recorded on a Bruker AV 400, $400 \mathrm{MHz}$ spectrometer with samples packed in zirconia rotors spinning at $5 \mathrm{kHz}$.

Flash chromatography was carried out using Macherey-Nagel silica gel $(0.04-0.063 \mathrm{~mm})$. Light petroleum refers to the fraction boiling in the range $40-60^{\circ} \mathrm{C}$. Chiral HPLC were performed using a Shimadzu LC-10AD pump with an SPD-M10A UV detector and Daicel columns. ${ }^{[18 \mathrm{e}]}$ Compounds 15a-c, e,f, h showed spectroscopic and analytical data in agreement with their structures. ${ }^{[18 \mathrm{e}]}$

\section{1-(3-Trimethoxysilylpropyl)-2,3-dimethylimidazolium Chloride (1)}

A mixture of 1,2-dimethylimidazole (3.84 g, $0.04 \mathrm{~mol})$ and (3chloropropyl)trimethoxysilane $(7.35 \mathrm{~mL}, 0.04 \mathrm{~mol})$ was heated under an argon atmosphere at $95^{\circ} \mathrm{C}$ for $24 \mathrm{~h}$. After cooling a viscous oil was formed. Diethyl ether was added and, after mechanical stirring with a spatula, a white solid was formed. It was filtered off then used immediately in the next step since it was highly hygroscopic. Therefore, $\mathrm{C}, \mathrm{H}, \mathrm{N}$-analysis was carried out after changing the chloride ion. ${ }^{1} \mathrm{H}$ NMR (acetone$\left.d_{6}\right): \delta=0.71-0.78(\mathrm{~m}, 2 \mathrm{H}), 1.85-1.91(\mathrm{~m}, 2 \mathrm{H}), 2.91(\mathrm{~s}, 3 \mathrm{H})$, $3.52(\mathrm{~s}, 9 \mathrm{H}), 4.11(\mathrm{~s}, 3 \mathrm{H}), 4.49(\mathrm{t}, J=7.3 \mathrm{~Hz}, 2 \mathrm{H}), 8.26(\mathrm{~d}, J=$ $2.1 \mathrm{~Hz}, 1 \mathrm{H}), 8.34(\mathrm{~d}, J=2.1 \mathrm{~Hz}, 1 \mathrm{H}) ;{ }^{13} \mathrm{C}$ NMR (acetone- $\left.d_{6}\right)$ : $\delta=7.0\left(\mathrm{SiCH}_{2}\right), 11.2\left(\mathrm{CH}_{3}\right), 25.1\left(\mathrm{CH}_{2}\right), 36.4\left(\mathrm{NCH}_{3}\right), 51.4$ $\left(\mathrm{CH}_{3} \mathrm{O}\right), 52.2\left(\mathrm{CH}_{2} \mathrm{~N}\right), 122.8,124.3,146.1$; IR (nujol): $\tilde{\mathrm{v}}_{\max }=$ $3393,1637,1464,1377,1192,1085 \mathrm{~cm}^{-1}$.

\section{1-(3-Trimethoxysilylpropyl)-2,3-dimethylimidazolium Tetrafluoroborate (2)}

To a solution of salt $\mathbf{1}(11.79 \mathrm{~g}, 0.04 \mathrm{~mol})$ in acetone $(15 \mathrm{~mL})$, sodium tetrafluoroborate $(4.61 \mathrm{~g}, 0.042 \mathrm{~mol})$ was added in one portion. The mixture was stirred at room temperature for $3 \mathrm{~d}$. After this time the mixture was filtered and the solution evaporated under reduced pressure. The residue was taken up with dichloromethane. A highly viscous material was formed. The solution was filtered under reduced pressure on a short pad of silica gel. The solution was evaporated under reduced pressure to give 2; yield: $8.50 \mathrm{~g}(61 \%)$; pale yellow oil. ${ }^{1} \mathrm{H}$ NMR (acetone- $\left.d_{6}\right): \delta=0.61-0.70(\mathrm{~m}, 2 \mathrm{H}), 1.88-1.94(\mathrm{~m}$, $2 \mathrm{H}), 2.73(\mathrm{~s}, 3 \mathrm{H}), 3.52(\mathrm{~s}, 9 \mathrm{H}), 3.89(\mathrm{~s}, 3 \mathrm{H}), 4.23(\mathrm{t}, J=7.4 \mathrm{~Hz}$, $2 \mathrm{H}), 7.55(\mathrm{~d}, J=2.2 \mathrm{~Hz}, 1 \mathrm{H}), 7.58(\mathrm{~d}, J=2.2 \mathrm{~Hz}, 1 \mathrm{H}) ;{ }^{13} \mathrm{C}$ NMR (acetone- $\left.d_{6}\right): \delta=6.9\left(\mathrm{SiCH}_{2}\right), 10.2\left(\mathrm{CH}_{3}\right), 24.9\left(\mathrm{CH}_{2}\right)$, $36.0\left(\mathrm{NCH}_{3}\right), 51.3\left(\mathrm{CH}_{3} \mathrm{O}\right), 51.5\left(\mathrm{CH}_{2} \mathrm{~N}\right), 122.4,124.0,146.3$; IR (liquid film): $\tilde{v}_{\max }=3568,3149,1708,1591,1541,1469$, 1421, 1192, $1057 \mathrm{~cm}^{-1}$; anal. calcd. for $\mathrm{C}_{11} \mathrm{H}_{23} \mathrm{BF}_{4} \mathrm{~N}_{2} \mathrm{O}_{3} \mathrm{Si}$ : C 38.16, H 6.70, N 8.09; found: C 38.54, H 6.72, N 8.13.

\section{1-(3-Trimethoxysilylpropyl)-2,3-dimethylimidazolium Hexafluorophosphate (3)}

According to the above procedure, compound $\mathbf{3}$ was obtained as a white solid; yield: $7.90 \mathrm{~g}(49 \%)$; mp $57-58^{\circ} \mathrm{C} .{ }^{1} \mathrm{H}$ NMR (acetone- $\left.d_{6}\right): \delta=0.61-0.67(\mathrm{~m}, 2 \mathrm{H}), 1.83-1.93(\mathrm{~m}, 2 \mathrm{H}), 2.74$ $(\mathrm{s}, 3 \mathrm{H}), 3.49(\mathrm{~s}, 9 \mathrm{H}), 3.90(\mathrm{~s}, 3 \mathrm{H}), 4.23(\mathrm{t}, J=7.4 \mathrm{~Hz}, 2 \mathrm{H}), 7.54$ $(\mathrm{d}, J=2.2 \mathrm{~Hz}, 1 \mathrm{H}), 7.58(\mathrm{~d}, J=2.2 \mathrm{~Hz}, 1 \mathrm{H}) ;{ }^{13} \mathrm{C}$ NMR (acetone- $\left.d_{6}\right): \delta=7.1\left(\mathrm{SiCH}_{2}\right), 10.3\left(\mathrm{CH}_{3}\right), 24.9\left(\mathrm{CH}_{2}\right), 36.1$ $\left(\mathrm{NCH}_{3}\right), 51.4\left(\mathrm{CH}_{3} \mathrm{O}\right), 51.7\left(\mathrm{CH}_{2} \mathrm{~N}\right), 122.5,124.1,146.3$; IR (liquid film): $\tilde{v}_{\max }=3618,3157,1706,1591,1541,1469,1419,1190$, $1072 \mathrm{~cm}^{-1}$; anal. calcd. for $\mathrm{C}_{11} \mathrm{H}_{23} \mathrm{~F}_{6} \mathrm{~N}_{2} \mathrm{O}_{3}$ PSi: C 32.67, H 5.73, N 6.93; found: C 32.99, H 5.80, N 6.80.

\section{1-(3-Trimethoxysilylpropyl)-4-methylpyridinium Chloride (7)}

A mixture of 4-methylpyridine $(3.89 \mathrm{~mL}, 0.04 \mathrm{~mol})$ and (3chloropropyl)trimethoxysilane $(7.35 \mathrm{~mL}, 0.04 \mathrm{~mol})$ was heated under an argon atmosphere at $95^{\circ} \mathrm{C}$ for $24 \mathrm{~h}$. After cooling the crude red oil was washed several times with diethyl ether then dried under reduced pressure; yield: $11.5 \mathrm{~g}(99 \%) .{ }^{1} \mathrm{H}$ NMR (acetone- $\left.d_{6}\right): \delta=0.68-0.75(\mathrm{~m}, 2 \mathrm{H}), 2.02-2.11(\mathrm{~m}$, 2H), $2.71(\mathrm{~s}, 3 \mathrm{H}), 3.48(\mathrm{~s}, 9 \mathrm{H}), 5.09(\mathrm{t}, J=7.2 \mathrm{~Hz}, 2 \mathrm{H}), 8.09$ (d, $J=6.4 \mathrm{~Hz}, 2 \mathrm{H}), 9.81(\mathrm{~d}, J=6.4 \mathrm{~Hz}, 2 \mathrm{H}) ;{ }^{13} \mathrm{C}$ NMR (acetone$\left.d_{6}\right): \delta=6.9\left(\mathrm{SiCH}_{2}\right), 22.6\left(\mathrm{CH}_{2}\right), 27.0\left(\mathrm{CH}_{3}\right), 51.4\left(\mathrm{CH}_{3} \mathrm{O}\right)$, $63.0\left(\mathrm{CH}_{2} \mathrm{~N}\right), 129.8,146.2,160.5$; IR (liquid film): $\tilde{v}_{\max }=3393$, 1641, 1190, $1076 \mathrm{~cm}^{-1}$; anal. calcd. for $\mathrm{C}_{12} \mathrm{H}_{22} \mathrm{ClNO}_{3} \mathrm{Si}: \mathrm{C}$ 49.39, H 7.60, N 4.80; found: C 49.60, H 7.65, N, 4.90.

\section{1-(3-Trimethoxysilylpropyl)-4-methylpyridinium Tetrafluoroborate (8)}

To a solution of salt $7(8.43 \mathrm{~g}, 0.029 \mathrm{~mol})$ in acetone $(15 \mathrm{~mL})$, sodium tetrafluoroborate $(3.33 \mathrm{~g}, 0.03 \mathrm{~mol})$ was added in one portion. The mixture was stirred at room temperature for 3 d. Work-up as for compound $\mathbf{2}$ gave compound $\mathbf{8}$ as a red oil; yield: $6.77 \mathrm{~g}(68 \%) .{ }^{1} \mathrm{H}$ NMR (acetone- $\left.d_{6}\right): \delta=0.63-0.70(\mathrm{~m}$, $2 \mathrm{H}), 2.05-2.14(\mathrm{~m}, 2 \mathrm{H}), 2.69(\mathrm{~s}, 3 \mathrm{H}), 3.49(\mathrm{~s}, 9 \mathrm{H}), 4.67(\mathrm{t}, J=$ 
$7.3 \mathrm{~Hz}, 2 \mathrm{H}), 8.02(\mathrm{~d}, J=6.2 \mathrm{~Hz}, 2 \mathrm{H}), 8.90(\mathrm{~d}, J=6.2 \mathrm{~Hz}, 2 \mathrm{H})$; ${ }^{13} \mathrm{C}$ NMR (acetone- $\left.d_{6}\right): \delta=6.9\left(\mathrm{SiCH}_{2}\right), 22.5\left(\mathrm{CH}_{2}\right), 26.5$ $\left(\mathrm{CH}_{3}\right), 51.3\left(\mathrm{CH}_{2} \mathrm{O}\right), 64.3\left(\mathrm{CH}_{2} \mathrm{~N}\right), 130.3,145.3,161.2$; IR (liquid film): $\tilde{v}_{\max }=3622,3554,1645,1575,1520,1475,1192$, $1075 \mathrm{~cm}^{-1}$; anal. calcd. for $\mathrm{C}_{12} \mathrm{H}_{22} \mathrm{BF}_{4} \mathrm{NO}_{3} \mathrm{Si}$ : C 42.00, H 6.46, N 4.08; found: C 42.20, H 6.59, N 4.15.

\section{1-(3-Trimethoxysilylpropyl)-4-aza-1- azoniabicyclo[2.2.2] octane Chloride (10).}

A solution of (3-chloropropyl)trimethoxysilane $(3.68 \mathrm{~mL}$, $0.02 \mathrm{~mol})$ and 1,4-diazabicyclo[2.2.2] octane $(6.73 \mathrm{~g}, 0.06 \mathrm{~mol})$ in acetonitrile $(10 \mathrm{~mL})$ was heated at $45^{\circ} \mathrm{C}$ for $24 \mathrm{~h}$. After cooling, the 1,4-diazabicyclo[2.2.2] octane salt crystallized. The solution was evaporated under reduced pressure then treated several times with hot diethyl ether. The salt was highly hygroscopic and difficult to handle, therefore, C,H,N-analysis was carried out after changing the chloride ion. ${ }^{1} \mathrm{H}$ NMR $\left(\mathrm{CD}_{3} \mathrm{OD}\right): \delta=0.62-0.74(\mathrm{~m}, 2 \mathrm{H}), 1.80-1.95(\mathrm{~m}, 2 \mathrm{H}), 3.15-$ $3.63(\mathrm{~m}, 14 \mathrm{H}), 3.59(\mathrm{~s}, 9 \mathrm{H}) ;{ }^{13} \mathrm{C}$ NMR $\left(\mathrm{CD}_{3} \mathrm{OD}\right): \delta=8.1,16.7$, 46.1, 53.4, 67.5; IR (liquid film): $\tilde{v}_{\max }=3381,1637,1464,1377$, $1059 \mathrm{~cm}^{-1}$.

\section{1-(3-Trimethoxysilylpropyl)-4-aza-1- azoniabicyclo[2.2.2] octane Tetrafluoroborate (11)}

Compound 10 (3.54 g, $0.011 \mathrm{~mol}$ ) was dissolved in methanol $(1.15 \mathrm{~mL})$ then acetone $(23 \mathrm{~mL})$ and sodium tetrafluoroborate $(1.31 \mathrm{~g}, 0.012 \mathrm{~mol})$ were added and the solution stirred at room temperature for $3 \mathrm{~d}$. After this time the mixture was filtered and the solution evaporated under reduced pressure. The residue was taken up with dichloromethane. The resulting cloudy solution was carefully filtered and the solution evaporated to leave a white solid; yield: $3.05 \mathrm{~g}(76 \%)$; mp $199-202{ }^{\circ} \mathrm{C} .{ }^{1} \mathrm{H}$ NMR (acetone- $\left.d_{6}\right): \delta=0.70-0.85(\mathrm{~m}, 2 \mathrm{H}), 1.85-1.98(\mathrm{~m}$, $2 \mathrm{H}), 3.15-3.52(\mathrm{~m}, 14 \mathrm{H}), 3.31(\mathrm{~s}, 9 \mathrm{H}) ;{ }^{13} \mathrm{C}$ NMR (acetone- $\left.d_{6}\right)$ : $\delta=9.9,17.0,46.5,53.6,67.6$; IR (nujol): $\tilde{v}_{\max }=1652,1473$, $1088 \mathrm{~cm}^{-1}$; anal. calcd. for $\mathrm{C}_{12} \mathrm{H}_{27} \mathrm{BF}_{4} \mathrm{~N}_{2} \mathrm{O}_{3} \mathrm{Si}$ : C 39.79, $\mathrm{H}$ 7.51, N 7.73; found: C 39.99, H,7.60, N 7.89.

\section{General Procedure for the Synthesis of Modified Silica Gels}

Compound 2 ( $1.73 \mathrm{~g}, 5 \mathrm{mmol})$ was dissolved in chloroform $(50 \mathrm{~mL})$ and treated with silica gel (Merck, $0.063-0.2 \mathrm{~mm}$, BET surface area $453 \mathrm{~m}^{2} / \mathrm{g}$, dried under vacuum and heated at $180^{\circ} \mathrm{C}$ overnight, $3.00 \mathrm{~g}$ ). The mixture was heated under reflux $\left(65^{\circ} \mathrm{C}\right)$ for $26 \mathrm{~h}$. After cooling to room temperature, the solid was isolated by filtration and washed with acetonitrile $(50 \mathrm{~mL})$ and diethyl ether $(50 \mathrm{~mL})$. The solid was dried under reduced pressure to give a powder.

Imidazolium-modified silica gel 4: ${ }^{13} \mathrm{C}$ NMR (solid state): $\delta=8.4,27.6,34.3,49.5,121.2,144.4$; UV: $\lambda_{\max }=223 \mathrm{~nm}$; IR: $\tilde{v}_{\max }=1575,1467 \mathrm{~cm}^{-1}$.

Pyridinium-modified silica gel 9: ${ }^{13} \mathrm{C}$ NMR (solid state): $\delta=8.6,21.3,28.9,62.2,128.4,143.5,159.7 ; \mathrm{UV}: \lambda_{\max }=227$ $255 \mathrm{~nm}$; IR: $\tilde{v}_{\max }=1645,1475 \mathrm{~cm}^{-1}$.

\section{General Procedure for the Supported Proline Materials}

In a round-bottom flask L-proline $(17.5 \mathrm{mg}, 0.15 \mathrm{mmol})$ and, when appropriate, ionic liquid $\left(\mathrm{bmimBF}_{4}, \mathrm{bmimPF}_{6}\right.$ or $\left.4 \mathrm{mbpBF}_{4}, 130 \mathrm{mg}\right)$ were dissolved in water $(0.4 \mathrm{~mL})$ and acetonitrile $(0.5 \mathrm{~mL})$ or in methanol $(0.9 \mathrm{~mL})$. To this solution the modified silica gel was added $(500 \mathrm{mg})$. The mixture was shaken for few minutes then evaporated under reduced pressure for $25 \mathrm{~h}$ to give a free-flowing powder.

\section{General Procedure for Aldol Reaction}

A solution of aldehyde $(0.5 \mathrm{mmol})$ in acetone $(1 \mathrm{~mL})$ was added to the $4 / \mathrm{bmimBF}_{4} /$ pro system $(650 \mathrm{mg}$, L-proline $30 \% \mathrm{~mol}$ ) or to 4/pro system $(520 \mathrm{mg}$, L-proline $30 \% \mathrm{~mol})$. The mixture was stirred at room temperature for $24 \mathrm{~h}$. After this time acetone was removed under reduced pressure and the modified silica gel taken up with diethyl ether and filtered under reduced pressure. The solution was evaporated, checked by NMR and finally purified by chromatography (light petroleum/ethyl acetate) to give the aldol product. The catalytic system was dried for a few minutes and then reused.

For the recycling studies the aldol reaction was also scaled up to four grams of modified silica gel with identical results.

(4R)-(4-Cyanophenyl)-4-hydroxy-2-butanone (15d): From light petroleum/ethyl acetate (2/1); white solid; mp 53$54{ }^{\circ} \mathrm{C}$; HPLC (Daicel Chiralpack OD-H, hexane/i-PrOH, 90/ 10 ; flow rate $1 \mathrm{~mL} / \mathrm{min}) t_{\mathrm{R}}$ (major $)=20.33 \mathrm{~min}, t_{\mathrm{R}}$ (minor) $=$ $22.83 \mathrm{~min} ;[\alpha]_{\mathrm{D}}^{22}:+55.3^{\circ}\left(\mathrm{c} 0.45, \mathrm{CHCl}_{3}\right) ;{ }^{1} \mathrm{H} \mathrm{NMR}\left(\mathrm{CDCl}_{3}\right)$ : $\delta=1.99\left(\mathrm{~s}, 3 \mathrm{H}, \mathrm{CH}_{3}\right), 2.62\left(\mathrm{~d}, J=6.2 \mathrm{~Hz}, 2 \mathrm{H}, \mathrm{CH}_{2}\right), 3.50(\mathrm{br} \mathrm{s}$, $1 \mathrm{H}, \mathrm{OH}), 4.99(\mathrm{t}, J=6.2 \mathrm{~Hz}, 1 \mathrm{H}, \mathrm{CH}), 7.26$ and 7.42 (each d, $J=8.1 \mathrm{~Hz}, \mathrm{ArH}) ;{ }^{13} \mathrm{C} \mathrm{NMR}\left(\mathrm{CDCl}_{3}\right): \delta=10.6,51.4,68.9$, 111.1, 118.6, 126.2, 132.2, 148.1, 208.2; IR (nujol): $\tilde{v}_{\max }=3420$, $2225,1707,1458,1377,1074 \mathrm{~cm}^{-1}$; anal. calcd. for $\mathrm{C}_{11} \mathrm{H}_{11} \mathrm{NO}_{2}$ : C 69.83, H 5.86, N 7.40; found: C 70.01, H 5.98, N 7.50.

\section{Acknowledgements}

Financial support from the University of Palermo (funds for selected research topics) and Italian MIUR within the National Research Project "Non-aromatic heterocycles in stereocontrolled processes" is gratefully acknowledged. Authors would like to thank Prof. H. García of the Departamento de Quimica, Universidad Politecnica de Valencia

\section{References and Notes}

[1] a) C. H. Heathcock, in: Comprehensive Organic Synthesis, Vol. 2, (Eds.: B. M. Trost, I. Fleming, C. H. Heathcock), Pergamon, Oxford, 1991, Chapters 1.5 and 1.6; b) B. M. Kim, S. F. Williams, S. Masamune, in: Comprehensive Organic Synthesis, Vol. 2, (Eds.; B. M. Trost, I. Fleming, C. H. Heathcock), Pergamon, Oxford, 1991, Chapter 1.7.

[2] a) T. Mukaiyama, Tetrahedron 1999, 55, 8609-8670; b) K. C. Nicolaou, D. Vourloumis, N. Wissinger, P. S. Baran, Angew. Chem. Int. Ed. 2000, 39, 44-122; c) D. A. 
Evans, A. M. Ratz, B. E. Huff, G. S. Sheppard, J. Am. Chem. Soc. 1995, 117, 3448; d) K. Narasaka, F.-C. Pai, Tetrahedron 1984, 40, 2233-2238; e) G. E. Keck, C. A. Wager, T. Sell, T. T. Wager, J. Org. Chem. 1999, 64, 2172-2173.

[3] D. A. Evans, K. T. Chapman, E. M. Carreira, J. Am. Chem. Soc. 1988, 110, 3560-3578.

[4] M. Haddad, J. Dorbais, M. Larchevêque, Tetrahedron Lett. 1997, 38, 5981-5984.

[5] a) B. M. Trost, Science 1991, 254, 1471-1477; b) B. M. Trost, Angew. Chem. Int. Ed. 1995, 34, 259-281.

[6] a) S. Masamune, W. Choy, J. S. Peterson, L. R. Sita, Angew. Chem. Int. Ed. 1985, 24, 1-76; b) S. Hanessian, A. Gomtsyan, N. Malek, J. Org. Chem. 2000, 65, 5623-5631.

[7] a) A. Yanagisawa, Y. Matsumoto, H. Nakashima, K. Asakawa, H. Yamamoto, J. Am. Chem. Soc. 1997, 119, 9319-9320 and references cited therein; b) E. M. Carreira, W. Lee, R. A. Singer, J. Am. Chem. Soc. 1995, 117, 3649-3650; c) D. A. Evans, D. W. C. MacMillan, K. R. Campos, J. Am. Chem. Soc. 1997, 119, 1085910860; d) Y. M. A. Yamada, N. Yoshikawa, H. Sasai, M. Shibasaki, Angew. Chem. Int. Ed. 1997, 36, 1871-1873; e) T. Ooi, K. Ohmatsu, D. Uraguchi, K. Maruoka, Tetrahedron Lett. 2004, 45, 4481-4484; f) B. M. Trost, E. Silcoff, H. Ito, Org. Lett. 2001, 3, 2497-2500; g) N. Yoshikawa, Y. M. A. Yamada, J. Das, H. Sasai, M. Shibasaki, J. Am. Chem. Soc. 1999, 121, 4168-4178; h) S. G. Nelson, Tetrahedron: Asymmetry 1998, 9, 357-389.

[8] a) S. E. Denmark, S. M. Pham, J. Org. Chem. 2003, 68, 5045-5055; b) S. E. Denmark, R. A. Stavenger, J. Am. Chem. Soc. 2000, 122, 8837-8847.

[9] a) K. Drauz, H. Waldmann, Enzyme Catalysis in Organic Synthesis, VCH, Weinheim, 1995, Vols. I and II; b) M. Utaka, H. Ito, T. Mizumoto, S. Tsuboi, Tetrahedron: Asymmetry 1995, 6, 685-686; c) J.-N. Cui, T. Ema, T. Sakai, M. Utaka, Tetrahedron: Asymmetry 1998, 9, 26812692.

[10] G. Zhong, D. Shabat, B. List, J. Anderson, S. C. Sinha, R. A. Lerner, F. C. Barbas III, Angew. Chem. Int. Ed. 1998, 37, 2481-2484.

[11] a) M. S. Nair, S. Joly, Tetrahedron: Asymmetry 2000, 11, 2049-2052; b) S. Joly, M. S. Nair, J. Mol. Catal. B: Enzym. 2003, 22, 151-160; c) A. Khilevich, A. Mar, M. T. Flavin, J. D. Rizzo, L. Lin, S. Dzekhtser, D. Brankovic, H. Zhang, W. Chen, S. Liao, D. E. Zembower, Z. Q. Xu, Tetrahedron: Asymmetry 1996, 7, 3315-3326; d) M. Edin, J.-E. Bäckvall, A. Córdova, Tetrahedron Lett. 2004, 45, 7697-7701.

[12] Reviews see: a) P. I. Dalko, L. Moisan, Angew. Chem. Int. Ed. 2004, 43, 5138-5175; b) R. O. Duthaler, Angew. Chem. Int. Ed. 2003, 42, 975-978; c) E. R. Jarvo, S. J. Miller, Tetrahedron 2002, 58, 2481-2495; d) P. I. Dalko, L. Moisan, Angew. Chem. Int. Ed. 2001, 40, 3726-3748; other interesting recent examples can be found in the following issues devoted to organocatalysis: Acc. Chem. Res. 2004, 37, 631-847; Adv. Synth. Catal. 2004, 346, p. $1007-1249$.

[13] a) B. List, R. A. Lerner, C. F. Barbas III, J. Am. Chem. Soc. 2000, 122, 2395-2396; b) K. Sakthivel, W. Notz, T.
Bui, C. F. Barbas III, J. Am. Chem. Soc. 2001, 123, 5260-5267.

[14] Review on proline-catalyzed reactions: B. List, Tetrahedron 2002, 58, 5573-5590; selected recent examples on proline-catalyzed aldol reactions: J. T. Suri, D. B. Ramachary, C. F. Barbas III, Org. Lett. 2005, 7, 1383-1385; b) R. I. Storer, D. W. C. MacMillan, Tetrahedron 2004, 60, 7705-7714; c) J. Casas, H. Sundén, A. Córdova, Tetrahedron Lett. 2004, 45, 6117-6119; d) Q. Pan, B. Zou, Y. Wang, D. Ma, Org. Lett. 2004, 6, 1009-1012; e) A. B. Northrup, I. K. Mangion, F. Hettche, D. W. C. MacMillan, Angew. Chem. Int. Ed. 2004, 43, 2152-2154.

[15] B. List, Acc. Chem. Res. 2004, 37, 548-557; for theoretical studies on proline-catalyzed aldol reaction, see: a) F. R. Clemente, K. N. Houk, J. Am. Chem. Soc. 2005, 127, 11294-11302; b) C. Allemann, R. Gordillo, F. R. Clemente, P. H.-Y. Cheong, K. N. Houk, Acc. Chem. Res. 2004, 37, 558-569; c) S. Bahmanyar, K. N. Houk, H. J. Martin, B. List, J. Am. Chem. Soc. 2003, 125, 2475-2479.

[16] a) Y. Sekiguchi, A. Sasaoka, A. Shimomota, S. Fujioka, H. Kotsuki, Synlett 2003, 1655-1658; b) Y. Hayashi, W. Tsuboi, M. Shoji, N. Suzuki, Tetrahedron Lett. 2004, 45, 4353-4356.

[17] a) D. E. Ward, V. Jheengut, Tetrahedron Lett. 2004, 45, 8347-8350; b) Z. Tang, Z.-H. Yang, L.-F. Cun, L.-Z. Gong, A.-Q. Mi, Y.-Z. Jiang, Org. Lett. 2004, 6, 22852287; c) I. Ibrahem, A. Córdova, Tetrahedron Lett. 2005, 46, 3363-3367; d) A. I. Nyberg, A. Usano, P. M. Pihko, Synlett 2004, 1891-1896.

[18] a) P. Krattiger, R. Kovasy, J. D. Revell, S. Ivan, H. Wennemers, Org. Lett. 2005, 7, 1101-1103; b) A. Hartikka, P. I. Arvidsson, Tetrahedron: Asymmetry 2004, 15, 1831-1834; c) H. Torii, M. Nakadai, K. Ishihara, S. Saito, H. Yamamoto, Angew. Chem. Int. Ed. 2004, 43, 19831986; d) E. Lacoste, Y. Landais, K. Schenk, J.-B. Verlhac, J.-M. Vincent, Tetrahedron Lett. 2004, 45, 8035-8038; e) Z. Tang, F. Jiang, L.-T. Yu, X. Cui, L.-Z. Gong, A.Q. Mi, Y.-Z. Jiang, Y.-D. Wu, J. Am. Chem. Soc. 2003, 125, 5262-5263; f) L.-X. Shi, Q. Sun, Z. M. Ge, Y.-Q. Zhu, T.-M. Cheng, R.-T. Li, Synlett, 2004, 2215-2217; g) A. Berkessel, B. Koch, J. Lex, Adv. Synth. Catal. 2004, 346, 1141-1146; h) A. J. A. Cobb, D. M. Shawn, S. V. Ley, Synlett 2004, 558-560; i) S. Saito, H. Yamamoto, Acc. Chem. Res. 2004, 37, 570-579; j) Z. Tang, Z.-H. Yang, X.-H. Chen, L.-F. Cun. A.-Q. Mi, Y.-Z. Jiang, L.-Z. Gong, J. Am. Chem. Soc. 2005, 127, 9285-9289.

[19] a) C. E. Song, S. Lee, Chem. Rev. 2002, 102, 3495-3524; b) Q.-H. Fan, A. S. C. Chan, Chem. Rev. 2002, 102, 33853466; c) D. E. De Vos, I. F. J. Vankelecom, P. A. Jacobs, Chiral Catalyst Immobilization and Recycling, WileyVCH, Weinheim, 2000.

[20] a) T. Welton, Chem. Rev. 1999, 99, 2071-2084; b) D. Zhao, M. Wu, Y. Kou, E. Min, Catal. Today 2002, 74, 157-189.

[21] M. Benaglia, M. Cinquini, F. Cozzi, A. Puglisi, G. Celentano, Adv. Synth. Catal. 2002, 344, 533-542; M. Benaglia, G. Celentano, F. Cozzi, Adv. Synth. Catal. 2001, $343,171-175$. 
[22] a) P. Kotrusz, I. Kmentová, B. Gotov, Š. Toma, E. Solčániová, Chem. Commun. 2002, 2510-2511; b) T.-P. Loh, L.-C. Feng, H.-Y. Yang, J.-Y. Yang, Tetrahedron Lett. 2002, 43, 8741-8743; c) A. Córdova, Tetrahedron Lett. 2004, 45, 3949-3952.

[23] S. Chandrasekhar, Ch. Narsihmulu, N. Ramakrishna, Reddy, S. Shameen Sultana, Tetrahedron Lett. 2004, 45, 4581-4582.
[24] M. Gruttadauria, S. Riela, P. Lo Meo, F. D'Anna, R. Noto, Tetrahedron Lett. 2004, 45, 6113-6116.

[25] C. P. Mehnert, Chem. Eur. J. 2005, 11, 50-56.

[26] I. Krossing, I. Raabe, Angew. Chem. Int. Ed. 2004, 43, 2066-2090. 